\title{
EXPLORING FAILURE AMONG SOCIAL ENTREPRENEURS - EVIDENCE FROM POLAND
}

\author{
Martyna Wronka-Pośpiech*
}

\begin{abstract}
Entrepreneurial failure and exit are critical components of the venturing process of social entrepreneurs. Failing and abandoning the pursuit of opportunities that seek to create social good affect also multiple stakeholders, whose well-being depends on the (public/social) value that the social enterprise provides. Given the nature of social entrepreneurship, this type of entrepreneur may present essential dissimilarities with their traditional counterpart in the way they cope with potential failure and exit. Because of the fact that researching failure in the context of SE is rather new, this paper uses a qualitative approach and bases on semi-structured interviews as a research method. With a lack of academic and case-based research on social enterprises that have failed, the goal of this research paper is to investigate and report on the underlying reasons why social entrepreneurs fail and to provide some insights into why talking about failure is beneficial to both current and future social entrepreneurs.
\end{abstract}

Keywords: failure, social enterprise, social entrepreneurship, entrepreneurial orientation.

\section{INTRODUCTION}

Although social initiatives aimed at solving social problems through economic means are not a new phenomenon, the interest in social entrepreneurship (SE) and the social enterprise development is still growing and the conviction about its significant role has surely gained ground. The term social entrepreneurship was not used before 1990 in Europe, and in the US not before the early 1990's (Defourny \& Nyssens, 2013, p. 33), which allows the impression of newness of the field. However, social entrepreneurship can be seen as a unique

\footnotetext{
University of Economics in Katowice. E-mail: martyna.wronka-pospiech@ue.katowice.pl
} 
concept that has its own, distinctive characteristics, which include the mission, motives and challenges (Dacin et al., 2010, p. 42). SE appears as an answer to the increasing disproportions between the rich and the poor and a response to the exclusion of large social groups from mainstream social life. Therefore, governments are promoting social enterprises as a mean of encouraging local economic regeneration, community engagement and improved public service delivery (Kerlin, 2006). The growing significance of research on social enterprises, in particular the impact of their performance on building the foundations of socio-economic growth in the national states, is confirmed, among others, by the recommendation issued by the European Commission to undertake extensive studies in the EU member states (EC, 2014a). The condition of social enterprises is of crucial importance for the achievement of social policy objectives and indirectly enables - through the inclusion of social groups that are excluded or are at the risk of exclusion - building cohesion in local communities and, more generally, in the whole country. Recently, an increasing number of studies recognize the key role of an individual - a charismatic leader, i.e. a social entrepreneur who combines the qualities of a businessperson with the ethos of a social activist. This unique combination of qualities (Zahra et al., 2009; Moreau \& Mertens, 2013; Wronka-Pośpiech et al., 2017) and managerial skills allows a social entrepreneur to effectively lead people, successfully manage risk and run efficient operation in the competitive market (Smith, Woodworth, 2012). As Abu-Saifan (2012, p. 22) social entrepreneur tailors his/her activities to create social value. He suggests that the social entrepreneur has no or little intention to create personal profit but to fulfill the social mission. Furthermore, the author refers to differences between commercial (profit-oriented) and social entrepreneur. In the similar vein, Peredo and McLean points to the creation of social value and other specific traits of social entrepreneurs, such as capacity to recognize and take advantage of opportunities to create that value, employing innovation, accepting an above-average degree of risk in the business, as well as being unusually resourceful and fearless when facing scarcity of resources. Although stories of success and growth have received much attention, existing literature is also criticized for being extremely positive (Zietsma \& Tuck, 2012), overemphasizing the abilities of the social enterprise activity to be scalable (Lumpkin et al., 2013), as well as idealizing social entrepreneurs themselves. However, as mentioned 
by Dacin et al. (2010) social entrepreneurship research could benefit from a stronger dialogue and understanding of entrepreneurial failure. With a lack of academic and case-based research on social enterprises that have failed, the goal of this research paper is to investigate and report on the underlying reasons why social entrepreneurs fail and to provide some insights into why talking about failure is beneficial to both current and future social entrepreneurs.

The structure of the paper is as follows. After an introduction, brief theoretical background is presented as the emphasis was placed on empirical exploration of social enterprises failures and successes. Because of the fact that researching failure in the context of SE is rather new, this paper uses a qualitative approach and bases on semi-structured interviews as a research method. Research results are presented in the fourth section, while the last part of the paper summarises theoretical and practical contributions, addresses research limitations and points to future research directions.

\section{SOCIAL ENTERPRISES IN POLAND}

A multitude of definitions of social enterprise exists and the field struggles with finding established definition that would satisfy various researches (Dacin et al., 2010). This partly results from the fact that theoretical and practical debate rolled simultaneously in three dominant schools of thought (the earned income, social innovation and EMES approach) (Starnawska, 2015a). Depending on the adopted approach, social entrepreneurship embraces a range of activities from the non-profit sector (e.g. activity of a pure NGO), through social entrepreneurship in a corporate setting, to commercial ventures having a social purpose. Furthermore, the characteristic organisational forms that social enterprises adopt depend on the existing legal frameworks, on the political economy of welfare provision, and on both cultural and historical traditions of non-profit sector development in each country.

In Poland, despite eight years of legislative effort, social enterprise is still an umbrella concept and neither official definition of social enterprise exists, nor a legal construct has been introduced into the system (Ciepielewska-Kowalik, et al., 2014). A number of organisations with diverse institutional forms have many of the distinctive features of social enterprises and are often referred to as such in the 
public discourse (i.e. non-profit organisations, cooperatives, vocational enterprises for the handicapped, vocational therapy workshops, social integration centres, social integration clubs and non-profit companies). These legal and organisational forms can be grouped in the three models of social enterprise (Ciepielewska-Kowalik, et al., 2014, p. 8-9). Each of them derives from a different pillar of organisations that stay close to a set of EMES criteria. These models of social enterprise are model 1 (traditional cooperatives and social cooperatives), model 2 (entrepreneurial non-profit organisations such as foundations, associations and other voluntary organisations), and model 3 (work and social integration social enterprises such as social enterprises for the disabled or social enterprises for wider group of persons threatened by social and economic exclusion). It should however be born in mind that, in spite of corresponding to the notion of social enterprise, out of many legal and organisational forms existing in Poland only social co-operatives fulfil the criteria of a social enterprise (see: Ciepielewska-Kowalik, et al., 2014, p. 8-9; EC, 2014b for details). Polish social cooperatives are based on the models of social cooperatives in Italy (type B), referred to as work integration social cooperatives and aiming at social and economic integration of individuals who are exposed to social and economic exclusion (EC, 2014b). They can be set up by natural persons but also by legal persons, among which can be NGOs, public authorities, and church units. However, majority of them (95\%) are natural persons' social co-operatives, when only $5 \%$ are legal persons' co-operatives (Starnawska, 2015b). They aim at social and economic integration of individuals who are exposed to social and economic exclusion (EC, 2014). Many existing social cooperatives dedicate themselves to inner-city community renewal by providing sustainable employment - including living wages, job training, and benefits - to hard-to-employ individuals. According to the most recent data, there are about 1482 social cooperatives in Poland. What can be observed is a significant growth in their number (in 2009 there were 187 social cooperatives, in $2010-276$, in $2011-425$, in $2015-1266$, and in 2017 - 1482), resulting from the support granted to setting up social enterprises with the investment of public money, mainly European funds. It is however estimated that around $40 \%$ of existing social cooperatives in Poland no longer conduct business activity. They are still on the register because they don't want or cannot - due to lack of knowledge or resources - carry out the winding-up process. No matter 
the reason for that decision, they have failed. The increasing importance of social economy in Poland results in the need to undertake research regarding principles and practises in the area of management. It is particularly important to understand the factors that determine both success and failure of these social enterprises.

\section{SOCIAL ENTREPRENEURS AND FAILURE}

Entrepreneurial failure and exit are important components of the entrepreneurial process as they have substantial consequences for the founder of the enterprise, the industry and the economy. This affects both commercial and social entrepreneurs in a similar way. However, in case of the latter, consequences are even more serious as they affect also multiple stakeholders, whose well-being depends on the (public/social) value that the social enterprise provides. Literature acknowledges social enterprises for their role in offering solutions and alleviating the social, ecological and economic problems that are overlooked, disregarded or unsuccessfully addressed by governments, private sector or civil society organizations (Mair \& Martí, 2006; Elkington \& Hartigan, 2008; Muscat \& Whitty, 2009; Zahra et al., 2009; Smith \& Woodworth, 2012; Defourny \& Nyssens, 2013). Generally, failure in social enterprises is divided into "financial failure" and "mission drift" (Dart, 2004; Bielefeld, 2007, p. 79), which makes failure of any organisation within third sector is difficult to conceptualize.

In Polish context entrepreneurial actions of social cooperatives also goes beyond the need to maximize profit for shareholders and owners, as they, above all, solve social problems, create workplaces for people at risk of social exclusion and professional marginalisation and engages in delivery of social services and work integration services for disadvantaged groups (such as people with disabilities) and communities. Therefore, combination of mixed value creation complicates the process of launching and running a social enterprise, threatens organisation's sustainability (Moizer \& Tracey, 2010) and in turn, makes experiencing failure and deciding to exit, more multivariate and challenging.

Actually, some authors disclose that social entrepreneurs are significantly more likely to fear failure and exit than their commercial counterparts (Harding \& Cowling, 2006). Entrepreneurial exit can be 
defined as "the process by which the founders of privately held firms leave the firm they helped to create; thereby removing themselves, in varying degree, from the primary ownership and decision-making structure of the firm" (DeTienne, 2010). Failure, on the other hand, is often simply described as the opposite of success. Although in most cases scholars' discussions are focused on best practices, the author intends to associate failure and exit with important part of the learning process. Eventually, analysis of unsuccessful social enterprises is also crucial to understand the barriers that lead to it failure, being those related to external constraints or internal factors.

\section{RESEARCH METHODS AND ANALYSIS OF 4 CASES OF SOCIAL CO-OPERATIVES}

Four cases, all being a part of bigger research project on social enterprises, are analysed in this paper: "Dekor", "Harmonia", "Klomb", and "Para-trans". All four cases have been selected purposively, with the emphasis put on the diversity in legal and organizational form (either natural persons' or legal persons' cooperative) and end result of entrepreneurial process (success or failure/exit). Primary data gathering process started in April 2016, however some prior findings being a result of authors field experience were used as a base for general considerations and identification of the reasons why social entrepreneurs fail to achieve assumed social and/or environmental impact. The data for the study was collected with the use of in-depth semi-structured interviews with social co-operatives' representatives as well as experts working in Social economy support centre (OWES) in Silesian voivodeship. Within the period of two years (2016-2017) the researcher has conducted 1-2 interviews in each cooperative. It is important to note, that the research has a good working relationship with organisations in question having served there as an external strategy consultant. Additionally, researcher's hands-on experience in empowering trainees working in the non profit sector through counselling, consulting, coaching and strategy development has equipped her with a perspective relevant to this study, allowing for successful data collection, on one hand, and facilitating communication with the cooperative, on the other hand. This approach is in line with Van de Ven's (2013) engaged scholarship, which emphasizes the co-production 
and co-ownership of the research process and challenges visions of academics as the sole knowledge producers and drivers of academic inquiry (Dempsey \& Barge, 2013).

Table 1. General description of participant in research interviews

\begin{tabular}{|l|c|l|l|l|}
\hline $\begin{array}{c}\text { Social co-oper- } \\
\text { ative name }\end{array}$ & $\begin{array}{c}\text { No. of co-oper- } \\
\text { ative members }\end{array}$ & $\begin{array}{c}\text { Social co-operative } \\
\text { member types }\end{array}$ & $\begin{array}{l}\text { Name and role } \\
\text { in the social } \\
\text { co-operative }\end{array}$ & $\begin{array}{c}\text { End result of } \\
\text { entrepreneur- } \\
\text { ial process }\end{array}$ \\
\hline Dekor & 5 & Natural persons & $\begin{array}{l}\text { Sonia, vice- } \\
\text { president }\end{array}$ & Success \\
\hline Harmonia & 7 & Natural persons & $\begin{array}{l}\text { Maria, presi- } \\
\text { dent }\end{array}$ & $\begin{array}{l}\text { Failure (and } \\
\text { exit) }\end{array}$ \\
\hline Klomb & 7 & Legal persons & $\begin{array}{l}\text { Ewelina, pres- } \\
\text { ident }\end{array}$ & Success \\
\hline Para-Trans & 11 & Legal persons & $\begin{array}{l}\text { Mariusz, pres- } \\
\text { ident }\end{array}$ & Failure \\
\hline
\end{tabular}

Source: own study.

On the other hand, numerous secondary data sources were used. First, prior academic literature devoted to entrepreneurial failure was reviewed in order to provide theoretical reasoning for the study. Secondly annual reports (e.g. Expertise on social economic conditions in numerous regions; Social Enterprise, Social Innovation and Social Entrepreneurship in Poland: National report), content available on the most important online portals (e.g. ekonomiaspoleczna.pl; spoldzielniasocjalnawpraktyce.pl; ashoka-cee.org/poland) were reviewed and analyzed in order to support evidence from field research. Apart from interviews, the researcher has also made c.a. 20 hours of observation and participated in two networking meetings organised for Regional Centre of Social Policy and Social economy support centres (OWES). In addition to the data collected in the course of the study the researcher also used her own experiences and personal notes from the period of time when she had been working with the social cooperatives as counsellor. This is in line with Eisenhardt (1989) and Yin (2003), who value the possibility of the joint use of different data collection techniques. In order to complement primary data, secondary data were used as well (the social cooperative website, newspaper articles, and annual reports). For the purpose of the study an inductive approach has been employed and, therefore, the author has not previously identified the theoretical framework categories. This paper, however, 
gives chance to present some introductory findings on the underlying reasons why social entrepreneurs fail and to provide some insights into why talking about failure is beneficial to both current and future social entrepreneurs.

\section{RESULTS}

"Dekor" was established in 2014 by 5 females following their handicrafts interests but also realising that both external funding and good support were available for social co-operatives in Poland. Dekor runs a shop in one of the major Polish cities with the population over 300,000. The merchandise range includes works and furniture from their own art studio and handicrafts made by them, senior craftsmen and young designers. Furthermore, Dekor organizes different workshops such as: felting, recycling, up cycling and renovation workshops or natural cosmetics workshop. As Sonia, one of the members emphasises, they create a community of friends. She says: "we decided to join forces and act together instead of alone. Back then we had two things in common - we were all unemployed and we all had different passions for handicrafts. It was enough to start." She also addresses the governance system in social cooperative, which indeed is specific and different from the one operating in for-profit businesses: "we try to employ participative decision-making process although it is challenging and not very popular in Poland. But I kind of see our strength in it. It makes Dekor more ours." All in all they display a good example of membership and the decision-making is based on democratic basis. When asked about experienced failures, Sonia says: "On one hand we are artists, we create... but on the other hand there is a market and the need to simply cover the costs. I feel like we suffer from tensions between the values... our ideological motivations versus the pragmatism. At some point being only and artist or craftsmen, whatever you call it, was not enough. There was the time when we couldn't sell anything for a day or two days... we were discouraged, we were not in a good place mentally and we needed to sort out some things... we had to switch our thinking and make good of our mistakes. That's how we came up with the idea of workshops. We tried different things and finally it worked." Sonia also express concern for places like Dekor: "I used to live in London where such initiatives are normal. We care about 
socializing people. We want them to get to know each other... but the bureaucracy frightens us. You know in England local authorites help you, local community support you, people are closer to each other... and everything is much simpler. In Poland concepts like kinship ties, trust and cooperative spirit are still abstract, which makes me very sad and discouraged." For that reason, in Dekor members are aware that they have to communicate efficiently and to develop a communication strategy as "good communication is crucial" (Sonia), and the speaking style needs to be adapted to the audience. Luckily members are well networked in the social enterprise landscape and in the local community. They are active in other bodies and associations for handicraftsmen and designers, managed to co-organize big fashion fairs and are well recognized in the local community.

"Harmonia" was established by 6 females and 1 male in 2013 and finished its existence 2 years later. Only 6 members were more or less active, the other one wasn't involved in coop activity and treated only as a figurehead. The main three fields of operation were: cleaning, catering and entertainment service for children. When asked about the reasons for the failure, Maria says: "When I first joined the cooperative it was still so-called initiative group. At the beginning we had to participate in many hours of trainings... mainly theory. There was a boom for NGOs in Poland back then. A lot of money from EU funds... and my conclusion is that those who benefited the most from it were people responsible for project management and also trainers, consultants. You know... it wasn't the ones who were supposed to benefit from it." When asked about support received in a start-up phase Maria says: "I want to warn all naive believers that such projects aren't written to help the unemployed in the first place. They are not... it is all about indicators... I feel cheated by theoreticians who have taught us about social coops having no idea what a coop really is in practice." The following opinion clearly shows how illusive can be a support for newly established cooperatives: "I will also mention the advisor we got for free as a part of the support system - nice, polite and of course not having enough knowledge about cooperatives to really help us..." Maria also emphasizes how important is the right choice of people in case of every business, including social cooperative: "two people, Luiza and Ilona, knew each other before joining the cooperative. So did Halina and Ewa. Me, Teresa and Jan did not know anyone... but even if we did it wouldn't matter... we were all from different planets. 
Didn't have much in common - apart from our job situation.” There are similar cases in different social co-operatives throughout Poland when random people are brought together in order to get pubic support and launch a social co-operative. Such cases rarely have positive end results. Maria also makes an interesting remark about the governance among members: "without formal job descriptions and responsibilities the chaos had prevailed... we argued with one another that some of us had to work hard while others wasn't doing enough. The enforcement of duties was a big problem... And here is to all teachers and trainers you really have to be very careful with what you get into potential co-operators' heads... all this stories about cooperative spirit and that everyone is the boss in the cooperative... those stories have no basis in the real world! They only make it hard to get people to do anything." Apart from internal issues there were also other problems - Harmonia started experiencing problems with economic sustainability very soon. According to Maria it all started with the wrong choice of premises: "we prepared our place, had fully equipped kitchen and playground under the roof for children. Now I know that it was a mistake because you could smell everything from the kitchen in the playground, not all customers liked it." Members started to leave coop gradually, mainly because of insufficient earnings. When bridge financing provided by the project also expired, Maria decided to sell some kitchen equipment and invest her own money to move cooperative to a cheaper location with lower standard. After few months, when Halina decided to leave, she gave up and launched a wind-down process for the cooperative. Today Maria suffers from nervous breakdown.

"Klomb" represents less common model of a social co-operative, being legal persons coop. It was established in 2010 by municipality and NGO focused on helping children and adults in difficult life situations. Klomb is located in a little town that experiences high unemployment rates and provides gardening and landscape services. It employs 1 female (president) and 6 males, all of which have previously been long-term unemployed. In the interviews Ewelina very often uses term "my company" or "my cooperative" when referring to Klomb. When discussing values she mentions: "for three months I did not take a penny for using my private, all for the benefit of my cooperative. I really wanted to have a job and I realised it will take time for the company to develop." She also speaks about difficulties during start-up stage: "I became a president due to my experience 
in working in a restaurant in the UK, which obviously had nothing to do with running a coop... nobody else was really engaged enough. The others have been recruited due to the project requirements and I still feel like they just want to get the job done and go home. They are happy that they have full time jobs and earn money. It is different for me... you know this company is my life now. At fist I knew nothing about managing people, so I've made all mistakes possible. I started asking myself is there anyone there who could help me? And the answer is - yep, there is! I've had countless and free of charge meetings with various advisors - marketing, HR, accounting... It has been of great help." It is interesting to notice, that Ewelina sees gradual development of the cooperative. She mentions it had a slow start, but by the end of the second year their position had gained ground in the local community. It is important to remember that activities of social enterprise usually constitute stakes for a large number of people or institutions: clients, beneficiaries, public authorities, local communities, other for-profit or social enterprises, etc. Moreover, the relationship between social enterprises and their stakeholders seems to be more important than in for-profit sector. It is reflected in Ewelina's remarks: "networking, identifying the groups to work with, and positioning my company within them is essential... do you really think I like going to events organised by the municipality? I don't... there's plenty of more interesting things to do besides harvest festivals and village fairs. But I know mayor needs to boast about launching first social cooperative in our town and alleviating social problems... And, you know, my presence there may actually result in new contacts for my cooperative." When asked about experienced failures, Ewelina says: "the black economy exists in all activities, but it is especially common in gardening services... now after 6 years our position is stable but if we were to operate in a fully free market I wouldn't say I can see a happy ending. I kind of see that as my personal failure... I am very close with our founding bodies, especially with the municipality. It is rather harmonic coexistence and codependence... I often have final say in many cases but you know... the reasons for such close ties are obvious - contracts, right?" This situation results from the fact that social co-operatives in Poland can be set up by natural persons or by legal persons, among which can be local public authorities as in this case. Although it does not involve direct public subsidies, it may lead to the co-operative 
dependence as some local authorities create social co-operatives to avoid the necessity of public procurement.

In 2013 the city where "Para-trans" operates decided to backtrack on transport for disabled people provided by municipal social welfare centre. One year later social co-operative was set up by two legal persons (city and foundation for social integration). The field of its operation is transport for disabled people. Coop owns 9 9-passenger minibuses adapted to passengers with all types of disabilities and currently employs ten drivers, previously employed in municipal social welfare centre. Although "Para-trans" is often presented as perfect example of how the city deals with a problem of providing transport for disabled people (both adults and children), Mariusz, the vice president, sheds some light on the day-to-day reality. First problems arose in 2016 as a result of the amended Act on the education system, imposing on municipalities the obligation to transport disabled children to kindergartens and schools. Mariusz confirms that as a result of this Act other disabled customers have to wait for the minibus even for a few hours: "we all want everything to come off rosy and peachy but it is just unreasonable... especially during school year, when most of our buses are transporting disabled students to or from school... Unfortunately, the number of student passengers has doubled last year. Earlier, we could refuse when it came to transporting a child with a mental disability if he or she could easily use public transport. Now with this new Act it is impossible... we are available for adult passengers only when we have time in the gaps between transporting children. Rush hours are the worst..." Such situations result in bad publicity in general and on social media, although it seems the city is the one to blame. If the city had been aware of obligation to transport children to schools, civil servants would have increased the number of vehicles to 15-20 minibuses. According to the contract, the city is obliged to pay for each kilometre travelled. Therefore, it is in the interest of this company to accept every order - however with 9 minibuses it is rather unmanageable. Apart from the above-mentioned problems Mariusz also refers to problems with staff motivation and fluctuation: "this is an exceptional job, you know... we are dealing with people with disabilities who require a lot of empathy and patience from us. You need to know how to behave when an autistic person gets an attack. You need to deal with it on your own. Not everyone is up to the task." When asked about others experienced failures, Mariusz says: "we fail almost every time when a car breaks 
down. The maintenance of cars is what steals my sleep in the nights. We spend all excess money to repair cars... we basically have to extra money because of it." He also mentions problem with coordination of activities and information flow: "it is also difficult that we have to be in touch with two departments: the social policy department and the education department, because we provide transport to both disabled adults and children. I don't remember there being such bureaucracy before... such an attitude of officials does not bode well for our future." Although the Para-trans seems to be well functioning cooperative, Mariusz describes their situation rather as failure, not a success and seriously considers leaving the cooperative.

\section{CONCLUSIONS}

The objective of this paper was to investigate and report on the underlying reasons why social entrepreneurs fail to achieve assumed social and/or environmental impact. Based on four case studies the author shows some practices and formalises general learning points on social enterprise failure factors, which - instead of being stigmatised should rather be analysed and discussed as sources of experiential value. These factors may depend upon people (both managers and employees) or may be placed in the environment of the organisation and in an organisation itself.

First of all, social enterprises are double bottom line organisations that do well while doing well financially. This is kind of a recurring theme as social entrepreneurs rely on governments or single stakeholders such as wealthy individuals and private corporations. Being dependent on these funding arrangements implies a risk of failure or bankruptcy once funding stops. Paradoxically, grants "spoil" grantees, who just live thanks to them and do not try to "become independent". Failures in regard resource dependency are expected to be solved with i.e. using bridge financing, but - ironically - in case of social enterprises that have a relatively low level of productivity and are in poor financial health, it may lead to a situation where the aid will contribute to artificially maintaining the undertaking in the market.

Another recurring theme in SE debate is tensions between values as social enterprises are permanently linked with conflicting goals, values, norms, and identities. Dealing with them at the same time not only 
creates tensions and competing demands, yet not attending to them precludes effectively understanding social enterprises. Furthermore, managers have to be able to analyse, understand, and even anticipate the market and social needs expressed by consumers, beneficiaries, the state, etc., which is even more difficult for social enterprises like legal persons social coop.

Social cooperatives also fail due to lack of proper integration, which is a difficult, and continuous process requiring sensitivity, openness to other people, energy and time devoted to each other. It is also the best investment in the team. Similarly, socialisation is an on-going process, which is not limited to the first few months of membership in the coop and needs to be encourages via a range of formal and informal socialisation activities. Raising the qualifications is also an indispensable element for the development of cooperatives, as it has an impact on both work efficiency but also on the self-esteem on the market.

Failures may also result from conditions in which social enterprises function, especially the low level of acceptance for social entrepreneurship in Poland (see more: Expertise on social economic conditions in Silesia region, 2016) and general lack of social trust among Poles as $74 \%$ are in favour of being cautious in dealing with other people (CBOS, 2016).

The research results come with a number of limitations that stem mainly from using only 4 semi-structured interviews as an empirical data set, which makes it hard to generalize or formulate universal conclusions. Inclusion of more cases into the analysis might have enriched the understanding of failure in the field of SE. Future studies may address this issue in different cultures and may even pursue comparative studies. Furthermore, the author is aware of the fact that future work on social enterprise requires studying other social enterprise models, not only social co-operatives.

Although the work accomplished by social entrepreneurs is not new, the current momentum behind the movement provides significant base and data for further observations. Given the fact that social enterprises are culture-specific, socially embedded, and community-tied, future research in other countries should also be undertaken. Conducting more empirical research such as case studies could help understand the research subject in other situations or contexts. Furthermore, little is known about the cognitive mechanisms and response strategies that social entrepreneurs use when coping with potential failure and exit. 


\section{REFERENCES}

Abu-Saifan, S. (2012). Social entrepreneurship: Definitions and boundaries. Technology Innovation Management Review, 2(2), 22-27.

CBOS (2016). Zaufanie społeczne. Komunikat z badań, nr 18. Fundacja Centrum Badania Opinii Społecznej, Warszawa.

Ciepielewska-Kowalik, A., Pieliński, B., Starnawska, M. \& Szymańska, A. (2015). Social Enterprise in Poland: Institutional and Historical Context. ICSEM Working Papers, 11. Liege: The International Comparative Social Enterprise Models (ICSEM) Project.

Dacin, P.A., Dacin, M.T. \& Matear, M. (2010). Social entrepreneurship: Why don't need a new theory and how we move forward from here. Academy of Management Perspectives, 24(3), 37-57.

Defourny, J. \& Nyssens, M. (2013). Social coops: When social enterprises meet the cooperative tradition. Journal of Entrepreneurial and Organisational Diversity, 2(2), 11-33.

Dempsey, S.E. \& Barge, J.K. (2013). Engaged scholarship and democracy. In: D.K. Mumby \& L.L. Putnam (eds.), Handbook of Organizational Communication: Advances in Theory, Research, and Methods (pp. 665-688). Thousand Oaks: Sage.

DeTienne, D. (2010). Entrepreneurial exit as a critical component of the entrepreneurial process: Theoretical development. Journal of Business Venturing, 25(2), 203-215.

Eisenhardt, K.M. (1989). Building theories from case study research. Academy of Management Review, 14(4), 532-550.

Elkington, J. \& Hartigan, P. (2008). The Power of Unreasonable People. Boston, USA: Harvard Business Press.

European Commission (2014a). A map of social enterprises and their eco-systems in Europe. Brussels: European Commission Directorate General for Employment, Social Affairs and Inclusion. Retrieved from: http://ec.europa. $\mathrm{eu} / \mathrm{social} / \mathrm{main} . j \mathrm{sp}$ ?langId=en\&catId=89\&newsId=2149 (access: 3.11 .2017 ).

European Commission (2014b). A map of social enterprises and their eco-systems in Europe. Country Reports: Poland. Brussels: European Commission Directorate General for Employment, Social Affairs and Inclusion. Retrieved from: http://ec.europa.eu/social/main.jsp?langId=en\&catId=89\&newsId=2149 (access: 3.11.2017).

Expertise on social economic conditions in Silesia region (2016). ROPS. Retrieved from: http://es.rops-katowice.pl/wp-content/uploads/2013/04/Ekspertyza_2016-10-20.pdf (access: 3.11.2017). 
Harding, R. \& Cowling, M. (2006). Social Entrepreneurship Monitor. London: London Business School.

Kerlin, J. (2006). Social enterprise in the United States and Europe: Understanding and learning from the differences. Voluntas, 17(3), 246-262.

Lumpkin, G.T., Moss, T.W., Gras, D.M., Kato, S. \& Amezcua, A.S. (2013). Entrepreneurial processes in social contexts: How are they different, if at all? Small Business Economics, 40(3), 761-783.

Mair, J. \& Martí, I. (2006). Social entrepreneurship research: A source of explanation, prediction, and delight. Journal of World Business, 41(1), 36-44.

Moizer, J. \& Tracey, P. (2010). Strategy making in social enterprise: The role of resource allocation and its effects on organizational sustainability. Systems Research and Behavioral Science, 27(3), 252-266.

Moreau, Ch. \& Mertens, S. (2013). Managers' competences in social enterprises: which specificities? Social Enterprise Journal, 9(2), 164-183.

Muscat, E. \& Whitty, M. (2009). Social Entrepreneurship: Values-Based Leadership to Transform Business Education and Society. Business Renaissance Quarterly, 4(1), 31-44.

Peredo, A.M. \& McLean, M. (2006). Social entrepreneurship: A critical review of the concept. Journal of World Business, 41(1), 56-65.

Smith, I.H. \& Woodworth, W.P. (2012). Developing social entrepreneurs and social innovators: A social identity and self-efficacy approach. Academy of Management Learning and Education, 11(3), 390-407.

Starnawska, M. (2015a). Przedsiębiorczość społeczna w społeczeństwie obywatelskim w Polsce. Studia BAS, 4(44), 167-203.

Starnawska, M. (2015b). Exploring governance among social co-operatives: Three models from Poland. Social Sciences, 4(90), 78-95.

Van de Ven, A.H. (2013). Engaged Scholarship: A Guide for Organizational and Social Research. Oxford: Oxford University Press.

Wronka-Pośpiech, M., Frączkiewicz-Wronka, A. \& Dobrowolska, M. (2017). Predicting managerial success in the case of polish social enterprises - personality perspective. In: Proceedings IFKAD 2017 (pp. 1689-1703). St. Petersburg, Russia, 7-9 June 2017, ISBN 978-88-96687-10-9 ISSN 2280787X.

Yin, R.K. (2003). Case Study Research (3 ${ }^{\text {rd }}$ edition). Thousand Oaks: Sage.

Zahra, S., Gedajlovic, E., Neubaum, D. \& Shulman, J. (2009). A typology of social entrepreneurs: Motives, search processes and ethical challenges. Journal of Business Venturing, 24(5), 519-532.

Zietsma, C. \& Tuck, R. (2012). First, do no harm: Evaluating resources for teaching social entrepreneurship. Academy of Management Learning \& Education, 11(3), 512-17. 
Bielefeld, W. (2009). Issues in social enterprise and social entrepreneurship. Journal of Public Affairs Education, 15 (1), 69-86.Dart, R. (2004). Being business-like in a non-profit organisation: A grounded and inductive typology. Nonprofit and Voluntary Sector Quarterly, 33(2), 290-310

Ciepielewska-Kowalik, A., Pieliński, B., Starnawska, M. \& Szymańska, A. (2015). Social Enterprise in Poland: Institutional and Historical Context, „ICSEM Working Papers", nr 11, Liege: The International Comparative Social Enterprise Models (ICSEM) Project. 


\section{BADANIE NIEPOWODZEŃ PRZEDSIĘBIORCZOŚCI SPOKECZNEJ - DOWODY Z POLSKI}

Większość rozważań dotyczących przedsiębiorczości, także przedsiębiorczości społecznej, koncentruje się na początkowych etapach procesu przedsiębiorczego. Duży nacisk kładzie się na rozpoznanie szansy i tworzenie nowych przedsięwzięć, natomiast mało uwagi poświęca się kwestii opuszczenia przedsięwzięcia. Odniesienie porażki i porzucenie możliwości mających na celu stworzenie dobra społecznego ma konsekwencje dla szerokiego grona interesariuszy, których dobrobyt zależy od wartości, jaką tworzy przedsiębiorca społeczny. Biorąc pod uwagę charakter przedsiębiorczości społecznej, tego typu przedsiębiorcy mogą wykazywać istotne różnice w stosunku do tradycyjnych przedsiębiorców w kontekście radzenia sobie z potencjalnymi niepowodzeniami, ich skutkami i koniecznością zakończenia przedsięwzięcia.

Wobec braku dociekań akademickich na temat porażki przedsiębiorców społecznych celem niniejszego opracowania jest zbadanie i przedstawienie przyczyn leżących u podstaw ich niepowodzeń. Zgodnie z przyjętymi celami badawczymi przeprowadzono 4 indywidualne częściowo ustrukturyzowane wywiady pogłębione z przedsiębiorcami społecznymi.

Słowa kluczowe: porażka, przedsiębiorstwo społeczne, przedsiębiorczość społeczna, orientacja przedsiębiorcza. 